\title{
Moral Realism and Philosophical Angst
}

\author{
JOSHUA BLANCHARD \\ Oakland University
}

Philosophers express angst about the existence of God, the immortality of the soul ${ }^{1}$, freedom of the will, the nature of mind $^{2}$, the metaphysics of modality ${ }^{3}$, and other subjects. On such issues, some of us do not only try to figure out what is true, we worry about it. Consider the case of theism. Positions range anywhere from the view that life is meaningless without God, to the view that it is terrible with God, with plenty of room between those extremes. ${ }^{4}$ Less attention has been devoted to similar questions in metaethics. Yet, just as someone might not only wonder, but worry about whether theism is true-so they might not just wonder, but worry about whether a particular metaethical theory is true. Given the immense importance of morality, it seems to me that there is much to explore in this area. This essay, I hope, begins to give angsty metaethics the attention that it deserves. ${ }^{5}$

After sketching a general account of philosophical angst, I describe and defend a particular instance of it: angst regarding moral realism. Following the convention in the

\footnotetext{
${ }^{1}$ Eli Hirsch $(2009,2,20)$ says that death and radical deception are "ineffably horrible" and "undermine everything that I have ever cared about in my life."

2 Jerry Fodor $(1989,77)$ says that “if it isn't literally true that my wanting is causally responsible for my reaching, and my itching is causally responsible for my scratching, and my believing is causally responsible for my saying.... If none of that is literally true, then practically everything I believe about anything is false and it's the end of the world."

${ }^{3}$ Robert Adams (1979) argues that modal realism justifies "moral indifference."

${ }^{4}$ See the essays recently published in Klaas Kraay (2018).

5 See also Guy Kahane (2012)'s pioneering work on what he calls the "value question in metaphysics." Although Kahane is more narrowly interested in evaluative judgments rather than full-fledged philosophical angst, this paper could be read partly as a metaethical contribution to the general research program advanced by Kahane.
} 


\section{Moral Realism and Philosophical Angst}

literature on the value of God's existence, in which "pro-theist" is used to refer to someone who thinks that it is good that God exists (whether or not they believe that God actually exists), I will use "pro-realist" to refer to someone who hopes that moral realism is true and worries that it might not be (whether or not they believe that realism is true). According to pro-realists, the truth of realism is extremely important for some further good, and there are no adequate alternatives: it is realism or bust. The phenomenon of pro-realism is immediately recognizable, but it is less obvious how one might understand and defend it. As long as moral nihilism is false, how could something of great normative significance hinge on which non-nihilistic metaethic is true? There are many non-realist metaethical theories that, by their own lights, vindicate the moral domain-so how could it be bad if one of those theories turned out to be true? This essay seeks to make angst about moral realism intelligible and to commend one way that pro-realists can make their case to the angst-free. That being said, I do not pretend to have exhausted the considerations that might motivate (or defeat) philosophical angst about moral realism.

\section{$\S 1 \quad$ Philosophical Angst}

Perhaps we know philosophical angst when we see it, but it is useful to have a more exact account in order to isolate the angst-inducing features of any particular domain. Here is how I understand the phenomenon: Philosophical angst is a complex cognitive judgment combined with a conative component. The cognitive judgment is that something existentially important is also irreplaceable. Existential importance is positive importance to the fundamental meaning, intelligibility, or overall value of our lives and the world. If you think that a claim might be false but do not think that its truth is 
important in this sense, then you do not count as angsty. Irreplaceability means that there is no available surrogate for whatever plays the important role in question. If you think that an existentially important claim might be false but you also think that some alternative claim would do just as well, then you do not count as angsty. The conative component, licensed by the judgment, is a kind of anxiety that what is important and irreplaceable in this sense is or might be unavailable. Notice that, to be philosophically angsty, one need not believe the claim that one is angsty about, but both the claim and its falsity must at least be live options. ${ }^{6}$

It should be no surprise that the most typical catalysts for philosophical angst are subjects including God, freedom, and death, rather than, say, the ontology of numbers or the semantics of counterfactuals. The former but not the latter subjects are especially significant in how we think about the meaning of our lives. But this explanation in terms of existential significance makes it at least somewhat surprising that metaethics is not subject to more angsty reflection than it is. After all, metaethics concerns the metaphysics, epistemology, semantics, and psychology of arguably the most important domain of value that there is-and minimally, a very important one. As a candidate for philosophical angst, metaethics seems intuitively closer to the philosophy of religion than to the ontology of numbers.

The metaethicist who most readily comes to mind as angsty is probably Derek Parfit. In On What Matters, Parfit famously (to some, notoriously) declares that, if

\footnotetext{
${ }^{6}$ For a full account of philosophical angst, see my “Philosophical Angst” (ms).
} 
metaethical non-naturalism is false, then nothing matters. ${ }^{7}$ This declaration satisfies the cognitive conditions for philosophical angst, provided that it includes or presupposes the thought that it is existentially important that something matters, and that no rival theory secures an adequate replacement for non-naturalist mattering. But Parfit's angst is narrower than it appears at first glance. He thinks that views rival to his collapse into nihilism or something very close to nihilism. And Parfit does not offer a substantive proposal for why things matter only on his metaethical view; rather, their mattering only on his view is an immediate logical or conceptual consequence of the ways that he has (somewhat idiosyncratically) defined the relevant terminology and concepts, as several commentators have pointed out. ${ }^{8}$ Because he thinks that his rivals' views collapse into nihilism, Parfit's angst really amounts to the worry that nothing matters if nihilism is true-a claim much less controversial than it seemed prior to clarification. Moreover, it is not even clear that Parfit thinks it would be a bad thing if nihilism were true. Indeed, in volume 3 of On What Matters, he distances himself from the claim that it matters whether something matters. ${ }^{9}$

These limitations of Parfit's angst provide a good foil for illustrating some of the central concerns of this essay. In contrast to Parfit, we might be angsty about metaethics not because we think that most views collapse into nihilism. We might instead worry that,

\footnotetext{
7 "If there were no such facts [facts that only "irreducibly normative claims" could state], and we didn't need to make such claims, Sidgwick, Ross, I, and others would have wasted much of our lives. We have asked what matters, which acts are right or wrong, and what we have reasons to want, and to do. If Naturalism were true, there would be no point in trying to answer such questions. Our consolation would be only that it wouldn't matter that we had wasted much of our lives, since we would have learnt that nothing matters" (Parfit 2011, 367).

${ }^{8}$ See Street (2017), Temkin (2017), and Driver (2017).

${ }^{9}$ See n. 15.
} 
despite the fact that many views do not collapse into nihilism, they nevertheless fail to accommodate something irreplaceably important to the meaning or intelligibility of our lives. This latter kind of angst permits more philosophical charity, because it evaluates theories on their own terms, allowing that they basically accomplish what they purport to. In this essay, I am wondering about metaethical angst in this richer, more charitable sense. While I will discuss realism's relationship to moral nihilism in its own right, I will not only discuss that; I am also interested in how realism compares to its non-nihilistic rivals - even when they succeed by their own lights. Compare: in thinking about freedom of the will, someone might be angsty if, in their view, only libertarianism about freedom secures something (in particular, libertarian freedom) that is both existentially important and irreplaceable. But this is substantively different from thinking that only libertarianism secures freedom in any sense. Someone (even a libertarian) may grant that compatibilist theories genuinely secure freedom of the will, but nevertheless still insist that such theories do not secure something extremely valuable or existentially important about the nature of freedom of the will, as it is described by libertarianism.

In short, angst about moral realism, or pro-realism, is the view that the truth of moral realism is necessary for something irreplaceable and existentially important to our lives going well, combined with the worry that realism might be false. This does not mean, however, that the pro-realist must think that all alternative theories collapse into moral nihilism.

\section{§2 How to be angsty about moral realism}




\section{Moral Realism and Philosophical Angst}

In this paper, I am chiefly concerned with moral realism in a fairly ambitious sense, though it is a research project in its own right to figure out which among realist options best satisfies certain existential concerns. According to moral realism in this sense, there are objective moral facts, and these can serve as the content of true beliefs in the same way that characteristically descriptive non-moral facts may do so (for example, the facts that human beings evolved or that two and two make four). We are able to know and express moral reality in propositional form, and we have, by-and-large, made genuine progress in moral inquiry. The moral facts are both necessary and radically response- or stance-independent, in that they are not fundamentally grounded in human minds or attitudes, whether individual, collective, actual, ideal, or otherwise hypothetical. This sort of picture, though loosely sketched, should be reminiscent of Enoch's (2016) "robust" realism, Eklund's (2017) "ardent" realism, and similar metaethical options. ${ }^{10}$ Eklund, for instance, identifies ardent realism as the view that "reality itself favors certain ways of valuing and acting" and says that the ardent realist "wants reality to undergird some ways of valuing over others," such that there is even reason to favor a unique concept of "good" over alternatives. ${ }^{11} \mathrm{I}$ agree with Eklund's sense that "ardent realist intuitions and motivations are widely shared," even if not everyone calls themselves by the name. Prorealism says that something about this picture irreplaceably plays an existentially important role in the meaning or intelligibility of our lives, and so the fact that realism

\footnotetext{
${ }^{10}$ Notice that I have said nothing about the naturalism/non-naturalism distinction, even though my flavor of moral realism is often associated with the latter. I am unbothered if my characterization of realism entails or otherwise requires non-naturalism, but I am also not committed to its doing so.

${ }^{11}$ Eklund $(2017,1,5)$.
} 
might be false warrants anxiety. ${ }^{12}$ It is not possible here to canvass all instances of nonrealism in their dizzying variety, so in what follows I will highlight three general contrasts: the contrast between realism and moral nihilism, between realism and anti-realism, and, finally, between realism and quasi-realism.

The reasons for judging that it would be bad if moral nihilism were true are distinct from the reasons for judging that it would be bad if any form of non-realism (including both anti- and quasi-realism) were true. Unlike moral nihilism, anti- and quasi-realist theories are what I will call vindicatory metaethics, in the sense that they (by their own lights) justify moral discourse and practice. In short, they are not self-conceived as error theories. The pro-realist, however, is not only hopeful that morality be given a vindicatory account, à la non-nihilism (a hope that anti- and quasi-realists may also satisfy), but that it be given a distinctly realistic account. It is not just morality per se that the pro-realist thinks enjoys existentially important irreplaceability, but morality realistically construed.

\section{\$2.1 The badness of moral nihilism}

Consider a simple example of an unmitigated injustice. In the History of the Peloponnesian War, Thucydides gives us an exchange between some Athenian invaders and their victims, the Melians. The Melians have no chance of resisting conquest. In

\footnotetext{
${ }^{12}$ Here it is worth noting that, in a continental context, my account of why the falsity of moral realism rightly induces philosophical angst is closest to the account of angst (or anxiety, or dread) one finds in Jean-Paul Sartre's Being and Nothingness and "Existentialism is a Humanism." Sartre locates the origin of anxiety in the fact that human beings are radically responsible not only for their own actions but for the very principles that guide them-in the sense that there is no objective, independent moral reality that determines this in advance. Of course, Sartre did not have in mind contemporary metaethical categories and one cannot know whether he would have also rejected anti-realism, but my account of the angst induced by non-realism is recognizably closer to his sense of angst than it is to, say, the systems of Soren Kierkegaard or Martin Heidegger, who have quite different concerns when they speak of angst.
} 
emphasizing the pointlessness of resistance, the Athenians accurately observe that "the strong do what they can and the weak suffer what they must."13 What does this have to do with metaethics? If moral nihilism is true-that is, if morality is bunk-then there is no moral problem with the aforementioned relationship between the strong and the weak. The dominance of the strong over the weak may be painful and even regrettable, but it would not be morally unjustified or otherwise morally objectionable. This is a good ground for angst about the prospect of moral nihilism, because it seems bad that there would be no grounds for objecting morally to this pitiful state of affairs. Not morally bad, of course-after all, nothing morally substantive follows from the truth of moral nihilism - but bad in some kind of non-moral sense; our lives (or, at least, the lives of the weak) are worse off if they lack grounds for moral objection. Accordingly, it seems appropriate to hope that morality is not bunk.

This simple argument is intuitive, but is the hope really reasonable? In what nonmoral sense is it "bad" to lack moral justification? As mentioned, it cannot be that moral nihilism results in some morally bad situation, since nihilism results in no morally valenced situations at all. Moreover, morality does not itself prevent the strong from doing what they can or the weak from suffering what they must; morality does not change the world. If morality does not change the world, then it is hard to see how nihilism would be bad even in a prudential or instrumental sense. What non-moral good does it do us that we can legitimately morally object to something, especially if it is just going to happen anyway?

13 Thucydides (1996, 5.89, 416). 
Nowadays it is common to distinguish between multiple domains of value, including but not limited to morality, meaning, aesthetics, and self-interest. Careful attention to these distinctions and their interaction in deliberation is, in my view, one of the significant accomplishments of $20^{\text {th }}$ century normative theory. One's life might be good along some of these dimensions but not others. A predominantly self-interested person might live a life abounding in prudential value (say, they always get what they want) but sorely lacking in moral value. Likewise, the "moral saint" might live a life abounding in moral value but sorely lacking in meaning. ${ }^{14}$ The acknowledgement that moral value does not exhaust the values that we should (and do) care about is an important advancement beyond a myopic focus on moral value.

But if philosophers of the past too often ignored the role that non-moral value plays in a good life, it is also important to see that moral value may contribute to, or even be required for, the fulfillment of the other kinds of value. It is true that a person's life may be abounding in moral worth yet lacking in meaning, but it is also true that a life entirely lacking in moral worth may-precisely in virtue of that lack-suffer from meaninglessness. In answering the question about what kind of badness accrues to us if nihilism is true, the pro-realist must appeal to one of the non-moral domains of value to which moral value nevertheless contributes. The domain of meaning is well-suited to this purpose.

What morality does, vis-à-vis the Athenian-Melian dynamic, is secure for us a particular normative standing in virtue of which we enjoy an authoritative claim against

\footnotetext{
${ }^{14}$ Susan Wolf, "Moral Saints."
} 


\section{Moral Realism and Philosophical Angst}

injustices. It is much better that we have this kind of standing and claim, even when we have no way of enforcing it. It is non-morally good to be morally worth treating well. Unjustified harms and oppression cause one's life to go poorly, but one's life is better if one has available an authoritative protest, even when it is ineffective. Such a protest secures meaning in the midst of harms; it reflects that one's condition is intelligible as morally unjustified, and objectionable on these grounds. There is no adequate, non-moral replacement for this standing and claim if morality is bunk. At best, the death of morality would leave in its wake various instrumental and epistemic norms, but these are not even inconsistent with the aims and values that the Athenians press against the Melians. Moral standing differs from other kinds of standing not in degree, but in quality. Over and above instrumental, epistemic, and other norms, moral standing provides the strong with a reason not to harm the weak.

This defense of angst about nihilism locates something that morality delivers for us and appeals to its irreplaceability and non-moral importance in our lives. It is worth noting that this view is consonant with some provocative, albeit narrower, remarks by Thomas Nagel regarding the importance of inviolability in any account of moral rights. Nagel writes, "What actually happens to us is not the only thing we care about: What may be done to us is also important, quite apart from whether or not it is done to us-and the same is true of what we may do as opposed to what we actually do" (108). Again, "not only is it an evil for a person to be harmed in certain ways, but for it to be permissible to harm the person in those ways is an additional and independent evil." And finally,

We can distinguish the desirability of not being tortured from the desirability of its being impermissible to torture us; we can distinguish the desirability of not being murdered from the 
desirability of our murder's being impermissible; we can distinguish the desirability of not being coerced from the desirability of its being impermissible to coerce us. These are distinct subjects, and they have distinct values. To be tortured would be terrible; but to be tortured and also to be someone whom it was not wrong to torture would be even worse (111).

Being the sort of being whom it is permissible to torture is bad, even despite the fact that it is in another way worse to be "killed unjustly than, say, accidentally." Nagel's point is not that permissible torture or murder are themselves worse than their impermissible counterparts; rather, it is "being someone it is not wrong to torture" that is worse than being someone it is wrong to torture-whether or not one is tortured.

Objection: What if a realist world is such that, even if or precisely because it has moral value, it is, on the whole, very bad for us-for example, if it is full of little more than intense and constant suffering, and the best normative theory says that the suffering is morally unjustified? Does the non-moral goodness of mere (violated) moral status really outweigh or otherwise trump such a state of affairs? Surely (this objection insists), a realistic possibility is only better than its nihilistic counterpart if the net value in the world, for us, turns out positive. In contrast to a very morally bad realistic world, an otherwise good or even so-so nihilistic world seems better for us. If moral nihilism is true, then what is otherwise unjust suffering is not morally bad at all; it is nothing, morally speaking. And it is plausible that a set of morally bad states is worse than a set of states that are neither morally good nor bad. So, perhaps it is not true as a general proposition that it is better if realism rather than moral nihilism is true. ${ }^{15}$

\footnotetext{
${ }^{15}$ This thought seems to motivate Kahane (2016). As noted above, it is also given expression at various points by Parfit in Vol. 3 of On What Matters, e.g., "It is a difficult question whether and how it matters whether anything matters. If we believe that suffering matters greatly, we may regret this fact. We might try to believe that, as Nihilists claim, nothing matters, because we have no reason to care about anything. We might then conclude in despair that Nihilism is false, because some things, such as suffering,
} 
In response to this objection, consider an implication of the view it commends. If an otherwise morally bad state is better if it is neither morally good nor morally bad, then finding out that one's otherwise unjust suffering is morally neutral should be encouraging news. If a would-be morally bad state (say, the state of being betrayed) was better on moral nihilism, then finding out that moral nihilism is true should be a kind of appropriate comfort for a person experiencing betrayal. Such a discovery would not alleviate a person's anger or unhappiness, but it would mean that they were not morally wronged, and that no particular reactions are morally justified.

But this appeal to moral nihilism for comfort is wrongheaded. It is better not only that there is moral value; it is better even that morally bad things really are so. If one is deciding between having a set of morally neutral things (say, trips to the beach) or a separate set of moral evils (say, trips to the torture chamber), then, all else equal, it is reasonable to choose the neutral things. If the question of preferring realism over nihilism were analogous to such a decision, then it would be reasonable to prefer nihilism in some of these cases. It is from this fact, I suspect, that the objection derives its plausibility. But this is not the right way to think about comparing metaethical possibilities. The would-be goods and evils must be held fixed in the comparison: this bit of would-be mercy, this instance of would-be wrongful treatment, etc. We are considering not just whether we

really do matter." Again, "I don't know whether I would be ... very disappointed if I came to believe that nothing matters in [the] reason-involving sense. I am not glad, for example, that suffering matters. But since I believe that we have reasons to care about suffering, and that we have other, weaker reasons to care about some other things, I am trying to understand these reasons better." Unlike Parfit, I am glad that suffering matters. 
have certain goods or evils period, but what it would be like if the very things we already rightly believe to be good or bad (like torture) were not really so.

In this way, contrasting moral nihilism and non-nihilism bears some similarity to contrasting first-order normative theories that have different evaluative upshots, with the aim of figuring out which would be better. When contrasting Kantianism and Utilitarianism, for example, it is not dialectically appropriate to radically change what the world is like when one imagines the truth of the rival theory. In wondering whether it would be better if Kantianism rather than Utilitarianism is true (as Nagel does in discussing the goodness of having inviolable personal rights), it is not dialectically appropriate to simultaneously toggle whether or not pleasure and pain states exist. Rather, one holds fixed the world as it otherwise is-including the existence of pleasures, pains, and rational capacities-and imagines the implications of Kantianism and Utilitarianism for this world.

To illustrate the general view on offer with an example, not only is torturing innocent uncles for fun morally bad, but we rightly do not want it to be otherwise. The question of whether torturing for fun is good or bad is not itself an evaluatively idle question. It is good for uncles, and for us, that it is impermissible to torture them for fun. This higher order desire is itself normatively justified, in addition to the justification for the first-order view itself. A world in which torturing innocent uncles is morally permissible, let alone good-holding everything else fixed-is worse than one in which it is morally evil. That is to say, it is to some extent better that torturing innocent uncles is morally bad rather than morally good. 
The intuition that the permissibility of torture would itself be bad is related to a popular normative objection to simplistic versions of divine command theory, according to which one ought to do whatever God happens to command. The objection says that such a theory allows God to make it the case that actually evil actions are good, and that this counts against the appeal of the theory. Returning to the Melian dialogue, the point here is not that the Melians should be happy that their moral claim and status are violated, nor should they wish that their violation was in fact permissible. Rather, the point is that they should prefer having a moral claim and status, given the facts that actually constitute the violation, to not having them.

Ultimately, one need not be convinced by the details either of Nagel's view or my view regarding, respectively, what is important about either a deontological first-order theory of morality or a non-nihilistic metaethic. Whatever one thinks are the goods (including non-moral goods) conferred by morality, these are vindicated by any nonnihilistic metaethical theory. In other words, take whatever goods you think are delivered by the best first-order moral theory. These goods are, in turn, vindicated by the true nonnihilistic metaethic, and it is to these that we can refer in justifying an angsty aversion to the possibility of nihilism. Notice that in order to reject this argument, you must think that morality makes no net-positive non-moral contribution to our lives. If, per impossible, we could choose whether to live in a morally nihilistic or non-nihilistic world, and could not appeal to moral values in making the decision, the person who rejects the argument of this section must say that we have no positive reason to choose the non-nihilistic world. And that, I think, is very implausible. 


\section{\$2.2 The badness of anti-realism}

To consider moral nihilism is to consider the possibility that there are none of the goods of morality; accordingly, these goods are dialectically available for licensing evaluative judgments about the possibility of moral nihilism. Moral anti-realism is trickier, because to consider anti-realism is to consider whether there are a great number of the goods of morality, but understood in an anti-realistic way. ${ }^{16}$ Speaking loosely, angst about moral nihilism is concern about the existence of morality, but angst about anti-realism is concern about the nature of morality.

The rest of this subsection applies to anti-realist theories other than quasi-realism, due to special complexities arising from the pan-expressivist or minimalist semantic program partly constitutive of quasi-realism. In going expressivist or minimalist at every level of discourse about the moral, the quasi-realist makes it especially difficult to say how quasi-realism differs from realism in its depiction of the moral domain, which in turn makes it difficult to say what is at stake between the two theories. Because this issue arises for none of the other varieties of anti-realism, it is useful to categorize and treat them separately.

So what is angst-inducing about (non-quasi) anti-realism? Why might it induce angst in someone if the moral badness of, say, murder is not realistically construed? Why might it induce angst in someone if moral facts are, say, constructions grounded in

\footnotetext{
${ }^{16}$ Note on terminology: There is an unfortunate terminological parallel between "pro-realism" and "antirealism." With "anti-realism" I refer to anti-realist metaethics, not an angsty aversion to moral realism. Elsewhere ("Preferring Moral Anti-Realism," ms.), I employ the somewhat unhappy label, "anti-moral realism", to refer to the angsty aversion to moral realism. In correspondence Selim Berker suggests "conrealism" as a slightly happier unhappy label.
} 
collections of subjective attitudes? Or if moral truths are contingent commitments that human beings have endorsed over time, for evolutionarily-specified purposes? Or if moral facts are, fundamentally, facts about the results of idealized decision-procedures among fully-informed agents?

Standard, longstanding disagreements between realists and anti-realists are suggestive of answers having to do with objectivity, non-contingency, and the like. I suspect that there is something potentially angst-inducing in the anti-realistic interpretation of each of these aspects of morality, but the answer that I want to pursue here has to do with what I take to be the radically independent character of moral justification if moral realism is true. Following Sharon Street, I regard some kind of mindor response-dependence of moral phenomena to be constitutive of moral anti-realism. Here is Street:

According to the anti-realist, if an agent has normative reason to $X$, then this conclusion must somehow follow from within her own practical point of view: if the conclusion that she has reason to $X$ is not entailed from within the standpoint constituted by her own set of evaluative attitudes, then she does not have that reason. ${ }^{17}$

As Street elaborates in a footnote, "the point of contention between realists and antirealists about normativity is the answer to the central question of Plato's Euthyphro (in rough secular paraphrase): are things valuable ultimately because we value them (antirealism), or do some things possess a value that holds independently of us and our attitudes (realism) ?"18 Street locates her own constructionist view on the anti-realist side of this "Euthyphronic" account of the debate. (Notice that Street's own exclusion of quasi-

${ }^{17}$ Street (2016): 295.

18 Street (2016) fn. 9. 
realism in this part of the discussion is what permits the Euthyphronic account, since quasi-realists emphatically deny that things possess moral value in a response-dependent way.)

Street's exact characterization is a bit too narrow for my purposes, since it seems to count idealizing theories as realistic. It is also too focused on an agent's normative reasons, rather than moral value and truth generally. The version of the realist/anti-realist distinction that will I utilize here counts our hypothetical, idealized, and collective responses as part of "us and our attitudes." So, here is the modified characterization of anti-realist theories that I will employ in what follows:

According to anti-realism, moral truths hold in virtue of us and our attitudes, broadly construed: if a putative moral truth is not grounded in our evaluative attitudes-whether actual or idealizedthen it is not a moral truth.

Following this taxonomy, if moral realism is true, then it is not just the case that our moral reasons are external in the traditional sense of being object-given, or intrinsic to the situations or objects that our reasons are about or for-after all, these very claims can be true in virtue of facts about moral agents qua valuing beings. And it is not just the case that moral properties are this way-after all, versions of anti-realism may claim that torture is wrong because it causes unjustified pain, not because anyone thinks it is wrong. It is the metaphysical grounds of such truths that are at issue. On realism of the "ardent" sort, we may have moral reasons, and things may have moral properties, in virtue of a system of moral truths that is itself independent of persons and their attitudes, and is in some sense favored by reality itself. Various metaethical parties offering positive accounts of morality may agree to some version of the claim that, for example, the 
suffering and oppression of the weak at the hands of the strong generates an object-given reason for us to care and do something, and that these reasons are reasons to stop something that is itself morally bad whether or not anyone thinks so. But there is an additional kind of independence involved in the true moral verdict, realistically construed: morality itself, the system of moral truths itself-or as Eklund says, "reality" itselfdeclares in favor of the oppressed, ruling their oppression a normative impossibility, with no reference to human moral attitudes in the grounds of this impossibility. When we think rightly, we concur with this verdict that did not come from us, either literally in our needing to issue it, or metaphysically in our attitudes, independent or collective, being needed to ground it.

Is angst on this basis intelligible? One way of beginning to see that it is at least intelligible is to appreciate that realistic independence is qualitatively rather than quantitatively different from anti-realistic independence. There is, the pro-realist should concede, a kind of anti-realistic independence that is a matter of degree or interpersonal distance, which I will call the quantitative sense of independence. Consider, for example, a view on which moral claims are true in virtue of their being the subject of hypothetical agreement among idealized agents. The pro-realist should not deny that there is a recognizable kind of independence involved in such an account. After all, this kind of view explicitly and literally distances moral truths from the actual responses of individuals. But notice that the view does not make moral truth at all independent of individual responses in what I call the qualitative sense. After all, on this kind of anti-realism, the responses of idealized agents are partly constitutive of the moral truth, and so the truth is still tethered 
to responses. The same goes for other response-dependent theories. For instance, any view on which moral claims are true in virtue of one's robust, consistent attitudes over time, would be a view on which there is independence, but it is independence of the antirealist kind that is explicable in terms of degrees of distance from the actual responses of individuals. Anti-realist moral truth is always tethered in some way to actual, individual responses.

In being qualitatively different, realistic independence is not just one more step on the ladder up and away from the actual attitudes of individuals. From the pro-realist point of view, for the system of moral truths to be fully independent is for it to be independent of our attitudes in any sense-wholly untethered from actual, individual responses. This is what I meant by the "radical independence" of moral truth-an independence that differs qualitatively from anti-realistic independence. After all, even the rational agreements among idealized agents would be themselves subject to the strictures and demands of a realistic morality. From the realist point of view, rational agreement among idealized selves might always produce true judgments, but such success is understood as the non-trivial success of tracking, rather than constituting or constructing, the independent truth.

I have made some effort to characterize the difference between realistic and antirealistic independence with an eye toward making intelligible why someone might be angsty about only having the latter, but I have not yet attempted to explain directly what would be so good (and irreplaceable) about realistic independence. First, a caveat: someone who finds moral realism of the sort described to be itself unintelligible will 
struggle to see how there can be anything other than degreed (or tethered) independence from individual responses. In a way, such a person is not the target of my argument, any more than the person who claims not to understand the concept of God is a target of arguments that it is good if God exists. On the other hand, I do want to show that, given that someone thinks that there is such a possibility as moral realism, it is at the very least rationally intelligible that they would not find anti-realist independence a fitting surrogate for realist independence. Fitting surrogates must be relevantly similar in kind to their originals, and I hope this discussion shows that anti-realist independence is not such a surrogate for realistic independence.

For the pro-realist, the radically independent nature of moral justification is good, but not merely good; it plays an existentially significant role in the meaning and intelligibility of life. This is because it militates against a kind of normative lonesomeness or moral bootstrapping, in which-in one way or another, at bottom-agents and their attitudes are responsible (either causally or constitutively) for providing our own moral vindication. ${ }^{19}$ Again, I reluctantly allow that pro-realist angst might be intelligible only from within the perspective of someone who "gets" what it would be like to see morality in a realist way, in which context radically independent moral truth and justification is

${ }^{19} \mathrm{Cf}$. the following extended excerpt from Wright (1995: 226), who makes a related point (though one whose import he ultimately rejects) about external sanction: "In general ... the immediate price of antirealism about morals is merely[!] that the gravity of moral judgement will lack an external sanction. When one is asked, 'Why bother to try to arrive at correct moral opinion?', the only available answer will be: because such an opinion informs better conduct-better, that is, from a moral point of view. The value of moral truth will thus be an instrumental, moral value. It is common to think that there are, by contrast, intrinsic, general values associated with pure discovery, understanding and knowledge of the real world. Properly to characterise and to understand such values seems to me to be a very difficult task. In any case, for the moral anti-realist, that kind of value cannot attach to moral truth. But I think it has seemed important that it should only because of the tendency of philosophers to suppose that there is nothing for truth to be that is not associated with value of that sort." 
available. Given a backdrop of such radical independence, there seems to be little difference, vis-à-vis moral bootstrapping, between the different degrees of quantitative, tethered independence available on anti-realism.

Consider an elaboration of the point via an analogy to circular reasoning. Relative to a realist framework, increasing the degrees of tethered independence is like increasing the length or complexity of a bit of circular reasoning for an immensely important conclusion. Imagine that you take yourself to have an "independent" (now, in the sense of non-circular) argument for an existentially important claim (say, that human beings are worthy of respect). You then encounter a group of theorists (these are the analogues to anti-realists) who give a variety of circular arguments for the important claim. If circular reasoning is all these theorists think there could ever be, then, perhaps, length and complexity is the most you could want or hope for in terms of independence. "What more could you possibly want?" such theorists may ask, incredulously. But once one sees-or takes oneself to see-an independent, non-circular route to the existentially important claim, it makes sense that the circular routes, including the longest and most complex among them, will pale in comparison.

It seems to me that, in the relevant respects having to do with existential concern, anti-realistically interpreted moral justification is to realistic justification as circular reasoning to an important claim is to non-circular reasoning for that claim. Crucially, the analogy is not supposed to establish that anti-realistic justification is somehow formally circular. Rather, the claim is that, contrasted with moral justification realistically 


\section{Moral Realism and Philosophical Angst}

construed, its grounds are similarly self-referential, in a sense that includes but is broader than formal circularity.

More can be said to defend the intelligibility of pro-realist angst. Although the considerations that follow do not depend on the analogy to circular reasoning, they are similar in spirit. Perhaps surprisingly, the perspective on offer here is sympathetic to (but not quite the same as) an argument due to the quasi-realist Simon Blackburn, who is hardly a friend of the sort of ardent moral realism in consideration here. Blackburn argues that several anti-realist views face a problem of moral relativism. For example, he offers the following objection to the constructivist metaethic associated with Christine Korsgaard, according to which each person is rationally bound to self-legislate moral norms in virtue of an inescapable practical identity. Korsgaard's view, he says, fails to preclude "pluralities of self-legislating persons whose identities are happily bound up in various constraints they set themselves under, but who unfortunately find these constraints in entirely different places." ${ }^{20}$ How does this relate to pro-realism? The prorealist may adapt Blackburn's worry into the present discussion by saying that what would be bad or regrettable about Korsgaardian constructivism-even if it turned out to be true-is precisely that, between any two different persons or communities of persons who locate normative constraints "in entirely different places," there is no radically independent source of authority to adjudicate the dispute, to vindicate either one side or none. This is reminiscent of the concern about moral bootstrapping that I expressed with

\footnotetext{
${ }^{20}$ Blackburn (1999: 219). It must be noted that Blackburn also criticizes several theses associated with realism on the same grounds: in particular, McDowell's sense theory and neo-Aristotelian accounts that ground morality in a conception of human flourishing (218-220).
} 
the analogy to circular reasoning: if everyone can appeal to "constraints they set themselves under", then they are ultimately justified self-referentially, by concerns that others need not share.

To illustrate the point by another route, consider yet another challenge by Blackburn, this time aimed squarely at the moral realist. Blackburn demands that the moral realist explain what more it is important to "say" about moral evils beyond the moral condemnation to which anti-realists are equally entitled. "What is wrong with [the Taliban in its relation to women] is that the men oppress the women, impoverish their lives, and keep them in a state of ignorance and inactivity. Why should we feel any urge to say more than that? Isn't it bad enough?"21 The pro-realist should reply: the urge is not that there be something else that we might say, but that there be more than just "we" saying it. The traditional realist answer was that the Taliban is not just wrong, but objectively and robustly so. The angsty realist does not deny that these are appealing aspects of the realist picture. But the really important point is that it is not the saying of such a thing that matters. It is rather that there is an independent verdict issued, as it were, by reality itself. What is "said" remains the same. Earlier I said that true moral statements "concur" with an independent verdict. The point is that true moral assertions are repetitions, restatements of a reality already partly constituted by the truths that the assertions express, much like two and two make four or no sphere has corners are, plausibly, reiterations of radically response-independent realities.

${ }^{21}$ Blackburn (1999: 223). 
Finally, it is worth considering a somewhat peculiar objection. The objection is worth considering not because it is necessarily powerful in itself, but because it helps to illustrate one further (and final) way of bolstering the intelligibility of pro-realist angst. Some readers might suspect that there is a kind of crypto-theism lurking in the background of the perspective here advanced, and they might want to launch a debunking argument against pro-realism on that basis. Isn't pro-realist just a watered down version of angst about the "death of God", who provided a kind of robust, external reference point for morality and meaning?

In a way, I think that the suspicions is right, but it actually provides confirmation of the overall framework defended here. Think of the familiar existential desires associated with theism: to "have God on our side", or not to be "alone in the universe," or to achieve and to see "cosmic" justice. ${ }^{22}$ These desires plausibly derive from fundamental religious attitudes for which realist value is also fitting. (Incidentally, they also provide additional support for David Killoren's recent argument that robust moral realism is a kind of "religion." ${ }^{23}$ ) Even if this connection may in turn provide grounds for a debunking argument against a certain style of religiously-infused moral theorizing, that is a matter of what is true, not what would be better-and irreplaceable. ${ }^{24}$ (It would, of

\footnotetext{
${ }^{22}$ The terms in quotation marks are pulled from the ether, not any particular source.

${ }^{23}$ David Killoren (2016), "Robust Moral Realism: An Excellent Religion," International Journal for Philosophy of Religion 79: 223-237.

${ }^{24}$ Nietzsche is probably the canonical debunker of this sort. Anscombe (1958) is widely regarded as offering a debunking argument along similar lines. According to the common reading, Anscombe argues that because modern moral philosophy is inextricably bound up with a Christian, legalistic conception of the world, and modern thought is non-theistic, we moderns ought to abandon modern moral philosophy for a tradition continuous with pre-Christian conceptions, especially ancient virtue ethics and an attendant moral psychology. However, because Anscombe was a devout Catholic who philosophized as such and in fact doubted the prospects of virtue ethics, this almost certainly is not the correct reading. Here I agree with Driver (2011), who reads Anscombe as offering "a modus tollens argument intended to establish the
} 
course, be disappointing for pro-realists if the very grounds of their angst could be employed as defeaters for realism itself!) Notice, too, that the sorts of replies that the angst-free may give to pro-realists are manifestly unsatisfying in their analogue religious form. To the pro-theist who desperately wants not to be "alone in the universe," it is hardly comforting that some naturalistic construal of God-say, that God is identical to humanity's highest ideals - also gives us a kind of company in the universe, in the form of our ideals being with us. If anything, the linkage to the religious case reinforces the intelligibility of angsty dissatisfaction with the falsity of realism.

None of this is to say that moral realism is true; the point is that it is intelligible to regard its truth as preferable to its falsity, and that we can come to appreciate the reasons why someone might so prefer. Put another way, were we-per impossible-deciding in advance what kind of nature the moral domain is to have, we would have some good grounds to select from ardently realist options. There is reason to want moral justification and vindication to be wholly untethered from our responses.

\section{\$2.3 The inexpressible badness of quasi-realism}

At a high level of abstraction, anti-realist theories are theories that attempt to accommodate our moral discourse and practice without the characteristic metaphysical commitments of realism, that is, without commitments to a realistic construal of moral facts, properties, truths, and the like. The radical independence of moral truth, accommodated only by realism, can therefore play a role in establishing an evaluative 
difference between realism and anti-realism partly because it amounts to a kind of independence that the standard-issue anti-realist explicitly denies, despite allowing for their own kind of degreed independence.

Things are not so easy with the quasi-realist, and this section seeks to explain (or mostly to kvetch about) why. Like the standard-issue anti-realist, the quasi-realist attempts to accommodate our moral discourse and practice without the characteristic metaphysical commitments of realism. Interestingly, this very fact suggests that whatever goes for pro-realism vis-à-vis its metaphysical differences with standard-issue antirealism should in turn apply to its differences with quasi-realism. But there is one crucial problem: the quasi-realist is an accommodationist in the extreme, seeking to, as a common boast goes, say anything that the realist can say. Anything? Yes-including statements that emit the strong aroma of realism, for example, "It is a responseindependent, objective fact that torturing for its own sake is wrong." Notoriously, if this project succeeds, then realists are precluded from identifying anything in the first-, second, or $n$ th-order moral domain that distinguishes them from quasi-realists. And if we cannot distinguish realism from quasi-realism descriptively, it seems that we cannot say what distinguishes it evaluatively. ${ }^{25}$ If there is no way to say how realism would be different from quasi-realism, then there is certainly no way to say why it would be

\footnotetext{
${ }^{25}$ With respect to quasi-realists themselves, things did not always look so bleak. In 1973 Blackburn defined "moral realism" as the view that "the truth of a moral utterances ... consist[s] in their correspondence with some fact or state of affairs", and he even declared it "false" (102). But by the 1980s, the hopes for distinguishing realism from its rivals went dramatically downhill with the increasing popularity of the minimalist theory of truth. See, for example, the struggles of Wright (1988).
} 
better. ${ }^{26}$ Due to quasi-realism's reliance on the minimalist notion of truth, according to which predicating truth of a proposition adds nothing substantial to the assertion of the proposition itself, the problem has become known as "the problem of creeping minimalism." ${ }^{27}$ The difficulty, in brief, is that if the anti-realist adopts a minimalist conception of truth that avoids identifying truth with what Crispin Wright calls "a property of intrinsic metaphysical gravitas," 28 then the sorts of truth-claims that otherwise distinguish the realist from the anti-realist can no longer do their work. ${ }^{29}$

While there is not room here to delve too far into this well-trodden territory, I will raise a suspicion about the state of the dialectic between quasi-realism and realism. This will in turn shed light on what pro-realists should say about quasi-realism-or more to the point, what they should say about not being able to say much at all.

The suspicious fact is that what makes quasi-realism and realism allegedly metaphysically indistinguishable is what you might take to be a purely semantic

${ }^{26}$ Combined with the point just made about metaphysical differences with anti-realism, we are left in a peculiar position. Given that quasi-realism adds nothing metaphysically to anti-realism, and that realism is certainly metaphysically different from anti-realism, it seems that there must be some difference-we just cannot say what it is.

${ }^{27}$ See Dreier (2004) for the classic contemporary statement of the problem. Dreier laments that "It's not as if one side had better be able to come up with something clever to say about how to distinguish realism from [quasi-realism] or else the other side wins. It's rather that those of us who feel confident that there is some difference between the two meta-ethical camps should be concerned that we don't know how to say what that difference is" (31). My argument in this section says that we have reason to be unconcerned that we don't know how to say what the difference is.

${ }^{28}$ Wright (1995: 213).

${ }^{29}$ Many metaethicists take the problem of creeping minimalism to be a problem for quasi-realists rather than realists. The thought is that, once quasi-realists adopt the minimalist program, it is they who have no way of explaining why they are not full-fledged realists. If that is right, then there is little sense in a prorealist being worried about the truth of quasi-realism, since quasi-realism is just disguised realism. What follows in the main text can be read as pursuing the other horn of an implicit dilemma-the possibility that the problem of creeping minimalism is really a problem for realists, that it is they who have no way of explaining what they add to quasi-realism. But if one thinks that it is quasi-realists who chiefly face this burden, then so much the better for pro-realism. 


\section{Moral Realism and Philosophical Angst}

maneuver-namely, the adoption of expressivism at every level of ethical and metaethical discourse. ${ }^{30}$ Such a maneuver only works (for the purposes of accommodating everything that realism accommodates) if reality is always exhausted by what we are able to say. To illustrate, imagine two figures: a conventional moral realist and an anti-realist who is expressivist about only first-order moral discourse. (The early emotivists can, without too much interpretative harm, be thought of in this way.) Both the conventional realist and first-order expressivist may agree in asserting any number of first-order moral sentences, for example, "Torturing for its own sake is morally wrong." However, they can also agree that the underlying metaphysic for each theory is different. Accordingly, they may disagree about various meta-moral, metaphysical sentences, for example, "The fact that torturing innocent uncles for fun is wrong is an objective, mind-independent fact in all possible worlds." They can then point to the object of the disagreement-the nature of moral facts-and ask whether it would be better for such facts to be realistic or antirealistic. Notice, too, that the first-order expressivist can, consistently with his own semantics, acknowledge that the kind of realistic independence highlighted in the previous section is not countenanced in his theory. He may even lament that fact.

But suppose that the first-order expressivist has an unusual conversion: he comes to endorse expressivism at all levels of discourse about the moral: he becomes a panexpressivist. What becomes of the previous disagreement over the sentence, "[T]he fact that torturing innocent uncles for fun is wrong is an objective, mind-independent fact in

\footnotetext{
${ }^{30}$ Here I am departing somewhat from the literature in identifying what we might call a problem of creeping expressivism rather than creeping minimalism.
} 
all possible worlds"? Merely by changing his semantics (but in a way that somehow changes nothing in his metaphysics), the pan-expressivist now putatively agrees with the realist. Moreover, he can taunt the realist as follows: "You realists claim to be endorsing something above and beyond what we anti-realists endorse-but what?" This challenge-"but what?"-is unanswerable in the dialectical context, since there is no expressible "what" for which the pan-expressivist cannot give an expressivist reading. And so he may also taunt the pro-moral realist, "You can't tell me what the difference is between our realism and quasi-realism, so why are you so angsty about it?"

What has the pan-expressivist done, dialectically speaking? I submit that he has simply taken away the realist's license to make distinctly realistic assertions-but only in the context of confronting pan-expressivism. Unfortunately, if the realist cannot make such assertions, then the pro-realist cannot go on to say, in light of some expressible difference, that it is better if realism is true, even if it is! Notice, crucially, that there is no good reason to think that the limits on what can be appropriately said are likewise limits on what the world is like. Even so, the realist is pushed into a narrow, involuntary mysticism. By "mysticism" I just mean any position that says there are truths that we are unable to express. ${ }^{31}$ Such mysticism is narrow, because the pro-realist is coerced into it only when engaging a pan-expressivist. It is involuntary, because there are no commitments or independent considerations on the side of the pro-realist that force or even so much as motivate it. For example, there need be no explicit thought,

\footnotetext{
${ }^{31}$ This is a much thinner notion of mysticism than one finds in, for example, the canonical discussion by William James, Varieties, 281-283.
} 
characteristic of independently motivated mysticism, that moral reality does outstrip our expressive capacities, though such a view may be very well-motivated in general. ${ }^{32}$ For these reasons, in the dialectical context of contrasting realism with quasi-realism, the prorealist is coerced into going mystical about both the difference between realism and quasi-realism, and therefore any evaluative judgment about that difference.

While the fate of the pro-realist at the hands of the quasi-realist is a philosophical injustice, the injustice is clear enough that one need not despair. To show that the prorealist's predicament lacks any metaphysical interest whatsoever, I will consider (and close with) three otherwise distant topics, where there are debates (either actual or merely possible) with surprisingly similar structural aspects: Berkeleyan immaterialism, theism, and the metaphysics of consciousness. In each of these debates, the pro-realist can find innocent companions in coerced mysticism, each of them falling victim to either a pan-expressivist gambit or something similar to it. Yet, in each case, it seems reasonable for the pro-realist's counterpart to remain angsty, despite being robbed of the expressive power to say why. On this basis, the pro-realist may remain confident that it is better if realism rather than quasi-realism is true, even if the realist lacks the dialectical license to say it to the quasi-realist's face.

\section{$\S 2.3 .1$ Berkeleyan immaterialism}

According to Berkeleyan immaterialism (henceforth just immaterialism), mental substance is the only kind of substance. A common misconception has it that there are

\footnotetext{
32 For examples of mysticism that is independently motivated in this sense, see Thomas Hofweber (ms), "Are there Completely Ineffable Aspects of Reality?"; Fodor's (1983:120ff.) discussion of "epistemic bounded[ness]"; McGinn (1989); and Chomsky (1988: 151-152).
} 
no external or physical objects of any kind according to this view, indeed no physical world at all. But immaterialism really just says something about such objects and the world-at the fundamental level, these are mentally constituted, and there is no need for an additional technical notion of physical substance. There are physical objects, but not in the kind of deep metaphysical sense posited by materialism. The ordinary category "physical" is just one of many kinds of ultimately mental substance. ${ }^{33}$

Immaterialism provides an illuminating surrogate for sophisticated quasi-realist positions in metaethics. What Berkeley accommodates vis-à-vis materialism and dualism, quasi-realists accommodate vis-à-vis moral realism. Berkeley can say anything that the materialist or dualist can say. Sentences like, "There are minds and bodies," "Some objects are physical," "There are objects other than minds," etc., are welcomed by the immaterialist. Yet these are just the sentences that one might have hoped would distinguish theses like substance dualism from its rivals! Crucially, Berkeley himself denies appeals to the materialist's technical notion of material substance; indeed, he denies that the notion is even intelligible. Likewise, the moral quasi-realist may deny the realist's technical notion of realistically construed, robust moral properties; indeed, quasi-realists commonly deny that such notions are even intelligible. But, with a gambit of the panexpressivist sort, there would be no need for the immaterialist to even deny talk of "material substance," provided it can be given an immaterialist reading.

33 "[C]ollections of ideas constitute a stone, a tree, a book, and the like sensible things - which as they are pleasing or disagreeable excite the passions of love, hatred, joy, grief, and so forth" (Berkeley, of the Principles of Human Knowledge, 1.1, emphasis mine). 


\section{Moral Realism and Philosophical Angst}

That we are all mental substances ultimately existing as ideas in the mind of God is not an evaluatively idle idea; it is something one might appropriately want not to be true. Unfortunately, it is impossible to explain what is so bad about this prospect to an immaterialist who can agree with any sentences uttered by the materialist or dualist. Yet, who thinks that there really is no difference-both descriptively and evaluativelybetween the truth of materialism and immaterialism? Those of us who are either uncommitted to either view, or committed immaterialists with a semantics that can express materialism, or committed materialists, can express perfectly well what is lacking on immaterialism: the material world. Yet, we are simply robbed of the dialectical license to offer such a sentence in the context of arguing with an immaterialist who offers some kind of pan-immaterialist semantic program.

\section{$\S 2.3 .2$ Theism}

Consider a much more familiar source of angst: God. Worries about God are more likely to induce philosophical angst than immaterialism. This is not a coincidence: while the alleged badness of naturalistic religion may bear formal analogies to the alleged badness of immaterialism, religion often plays a central and existentially important a role in human life more akin to moral value. ${ }^{34}$

Although debates between traditional theists and atheists are most familiar to philosophers and non-philosophers alike, there is also a dispute between supernaturalist religion (henceforth, supernaturalism) and naturalist religion (henceforth, naturalism). Naturalists deny supernaturalist metaphysics, but seek to provide a positive account of

\footnotetext{
${ }^{34}$ Much of this, I suspect, has to do with what I say regarding "crypto-theism" above.
} 
religious discourse and practice. ${ }^{35}$ Provided that something natural can play the role of the supernaturalist God, the naturalist may give naturalistic readings of various kinds of religious propositions-for example, that God exists or that God loves us. But even if the naturalist succeeds at this project of accommodating first-order religious discourse and practice, it is manifest both that naturalists and supernaturalists differ at the level of metaphysics, and that this has significant evaluative upshot. As long as the naturalist remains a second-order descriptivist, the supernaturalist and naturalist can agree that their metaphysics at the first-order level are different.

But the naturalist may decide to play dirty. If he adopts a religious semantics in which all first-, second-, and nth-order religious discourse can come out true even without the truth of traditional theism, then the supernaturalist is robbed of his dialectical license to offer any first-, second-, or nth-order religious sentences that would otherwise distinguish the two theorists' metaphysics.

That there is no God in the traditional sense is not just an evaluatively indifferent idea; it is something one might intelligibly want not to be true. But it is impossible to appropriately explain what is so bad about this prospect to a naturalist who can agree with any sentences uttered by the supernaturalist. Yet, who thinks that there really is no difference-both descriptively and evaluatively-between the truth of supernaturalism and naturalism? Those of us who are either uncommitted to either view, or committed naturalists with a semantics that can express supernaturalism, or committed supernaturalists, can express perfectly well what is lacking on naturalism: God. Yet, we

\footnotetext{
${ }^{35}$ See especially Johnston (2009) and Dworkin (2013).
} 


\section{Moral Realism and Philosophical Angst}

are simply robbed of the dialectical license to offer such a sentence in the context of arguing with a naturalist who offers some kind of pan-naturalist semantic program.

\section{$\S 2.3 .3$ Consciousness}

Finally, consider a slightly less familiar source of angst from a still-familiar topic: consciousness. Consciousness does induce philosophical angst, though perhaps not as much as naturalism or anti-realism. But it does, in many people's conceptual schemes, play an important role. For example, according to many philosophers, consciousness marks much of what is most valuable in the universe. A world of metaphysical zombies would be a much worse world than ours, at least with respect to the value contributed by consciousness itself.

Imagine a philosopher named "David." David believes that, in addition to physical stuff in the world, there is mental stuff, in particular, there is consciousness. Moreover, David thinks that, even if we cannot quite say what consciousness is in non-mental terms, we all (provided we are conscious) more or less have access to the fact of its existence.

David disagrees with Phillip, who believes that there is no such thing as consciousness. Not only that, but they disagree over what they agree is a single proposition: that there is consciousness. It is dialectically appropriate for David to say to Phillip, "My view is different from yours, because my view posits consciousness." This expressible descriptive difference allows them to maintain an evaluative dispute about whether it is better or worse for there to be consciousness in the world. Hence it is also dialectically appropriate for David to say to Phillip, "It would be better if my view were 
true, because only my view accommodates the irreplaceable, important good that is consciousness."

But now Phillip calls over his cousin, Daniel. Helpfully for our purposes, Daniel adopts a semantics in which all first-, second-, and $n$ th-order discourse about the mental can come out true even without the existence of consciousness in David's sense. Hence, David is robbed of his dialectical license to offer any first-, second-, or $n$ th-order sentences that would otherwise distinguish his metaphysics from Daniel's. David can, of course, turn to Phillip and rightly say, "You and I both know that Daniel doesn't really believe in consciousness," but such a sentence cannot appropriately be offered to Daniel himself.

What the above three examples-material objects, God, and consciousness-show is that it is possible to adopt a semantic or related program that takes away an interlocutor's dialectical license to appropriately offer any first-, second-, ... or $n$ th-order sentences in the relevant domain in order to distinguish the metaphysics of the two theories in question. Consequently, it becomes impossible to give a descriptive account of what makes one angsty in the domain. After all, one cannot intelligibly evaluate what one cannot identify in the first place. Hence, the pro-realist is not the only sort of person coerced into what I have called involuntary mysticism. There are companions in metaphysics, philosophy of religion, philosophy of mind, and elsewhere.

What should we conclude from this, vis-à-vis the truth of pro-realism? Although the pro-realist is prevented from appropriately defending the claim that it would be worse if quasi-realism were true in the narrow dialectical context of engaging an actual quasirealist, the assertion may still be maintained in every other context. There are no good 
reasons for thinking that what goes for realism versus anti-realism generally, does not also go for realism versus quasi-realism. There are only good reasons to think that the pro-realist lacks the dialectical license to say so to the quasi-realist. As we have seen, the pan-expressivist gambit of the quasi-realist makes no metaphysical difference to the distinction between realism and non-quasi anti-realism; hence it must also make no evaluative difference. So, just as the realistic independence of moral vindication justifies the hope that realism rather than anti-realism is true, so it justifies the hope that realism rather than quasi-realism is true. This much, at least, we can affirm when the quasi-realist is not in the room.

\section{$\S 3$ Conclusion}

In this paper, my ultimate goal has been to commend the research program of angsty metaethics and the exploration of metaethical value judgments. To this end, I defended the claim that it is much better that moral realism rather than any of its rivals is true. ${ }^{36}$

\section{References}

Adams, Robert. 1979. "Theories of Actuality." Nous 8, no. 3: 211-231.

Anscombe, Elizabeth. 1958. "Modern Moral Philosophy." Philosophy 33 (124): 1-19.

Blackburn, Simon. 1973. "Moral Realism." In Morality and Moral Reasoning, ed. J. Casey. Methuen, London.

- 1999. "Is Objective Moral Justification Possible on a Quasi-Realist Foundation?" Inquiry 42, 2: 213-227.

Chomsky, Noam. 1988. Language and Problems of Knowledge: The Managua Lectures. Cambridge, MA: The MIT Press.

Dreier, James. 2004. "Meta-Ethics and the Problem of Creeping Minimalism." Philosophical Perspectives 18: 23-44.

\footnotetext{
${ }^{36}$ For helpful discussion and feedback on this paper l'd like to thank Spencer Case, Terence Cuneo, Raff Donelson, Luke Elson, David Faraci, Krasi Filcheva, Eli Hirsch, Zoë King, Barry Maguire, Ram Neta, Derek Parfit, Ryan Preston-Roedder, Geoffrey Sayre-McCord, Russ Shafer-Landau, Keshav Singh, Larisa Svirsky, Silvan Wittwer, and Susan Wolf. I am also grateful to audiences at the 2017 Rocky Mountain Ethics Congress and the 2018 Great Lakes Philosophy Conference.
} 
Driver, Julia, "Gertrude Elizabeth Margaret Anscombe", The Stanford Encyclopedia of Philosophy (Winter 2014 Edition), Edward N. Zalta (ed.), URL = <https://plato.stanford.edu/archives/win2014/entries/anscombe/>.

- - . 2017. "Contingency and Constructivism." In Simon Kirchin (ed.), Reading Parfit: On What Matters. New York, NY: Routledge.

Dworkin, Ronald. 2013. Religion Without God. Cambridge, MA: Harvard University Press. Fodor, Jerry. 1989. "Making Mind Matter More." Philosophical Topics 27, no. 1: 59-79.

- - . 1983. The Modularity of Mind: An Essay on Faculty Psychology. Cambridge, MA: The MIT Press.

Hirsch, Eli. 2009. "Diabolical Mysticism, Death, and Skepticism." Philosophic Exchange 39: 2-27.

Hofweber, Thomas. Ms. "Are there Completely Ineffable Aspects of Reality?"

James, William. 1997. The Varieties of Religious Experience. New York, NY: Touchstone. Johnston, Mark. 2009. Saving God. Princeton, NJ: Princeton University Press.

Kahane, Guy. 2011. "Should We Want God to Exist." Philosophy and Phenomenological Research 82, no. 3: 674-696.

- - . 2012. "The Value Question in Metaphysics." Philosophy and Phenomenological Research 85, no. 1:27-55.

-- - 2016. "If Nothing Matters." Nous 50, no. 2: 1-27.

Killoren, David. 2016. "Robust Moral Realism: An Excellent Religion," International Journal for Philosophy of Religion 79: 223-237.

Kraay, Klaas (ed). 2018. Does God Matter? Essays on the Axiological Consequences of Theism. New York, NY: Routledge.

Mavrodes, George. 1986. "Religion and the Queerness of Morality." In William Wainwright and Robert Audi (eds.), Rationality, Religious Belief, and Moral Commitment. Cornell University Press: 213-226.

McGinn, Colin. 1989. "Can We Solve the Mind-Body Problem?" Mind 98, 391: pp. 349366.

Nagel, Thomas. 2007. "The Value of Inviolability." In Paul Bloomfield (ed.), Morality and Self-Interest. Oxford University Press: 102-114.

Parfit, Derek. 2011. On What Matters (vol. 2). Oxford: Oxford University Press.

Sartre, Jean-Paul. Being and Nothingness.

Street, Sharon. 2016. "Objectivity and Truth: You'd Better Rethink It." In Russ ShaferLandau (ed.), Oxford Studies in Metaethics vol. 11.

- - - 2017. "Nothing 'Really' Matters, But That's Not What Matters." In Peter Singer (ed.), Does Anything Really Matter? Essays On Parfit On Objectivity. Oxford: Oxford University Press.

Temkin, Larry. 2017. "Has Parfit's Life Been Wasted? Some Reflections on Part Six of On What Matters." In Peter Singer (ed.), Does Anything Really Matter? Essays On Parfit On Objectivity. Oxford: Oxford University Press.

Thucydides. 1996. History of the Peloponnesian War, ed. by Robert B. Strassler, trans. by Richard Crawley. New York, NY: Touchstone.

Wolf, Susan. 1982. "Moral Saints." Journal of Philosophy 79(8): 419-439. 
Wright, Crispin. 1988. "Realism, Anti-realism, Irrealism, Quasi-Realism." Midwest Studies in Philosophy 12: 25-49.

- 1995. "Truth in Ethics." Ratio 8, 3: 209-226. 